\title{
Attitude of University Students and Teachers towards Instructional Role of Artificial Intelligence
}

\author{
Dr. Irshad Hussain \\ Professor \\ Department of Education, IUB \\ irshad_iub@yahoo.com
}

\begin{abstract}
The present study evaluated the attitude of university students and teachers towards instructional role of artificial intelligence. It was a descriptive study and the researcher used survey approach for data collection. The data was collected from 323 university students and 196 university teachers by using two questionnaires developed (one for students and one for teachers) on five point rating (Likert) scales. Descriptive statistics i.e. percentage was used for data analysis. This study demonstrated positive attitude of university students and teachers towards AI and its instructional role. It appeared to be encouraging for the respondents as well as for the administrators and policy makers. The study suggested higher education institutions to formulate a feasible policy to get benefits of instructional role of AI in higher education.
\end{abstract}

Keywords: Artificial Intelligence, Innovation, Digital Technologies, Instructional Role, Personalized Learning

\section{Introduction}

Knowledge, information, and information \& communication technologies (ICTs) appear to be the dominating traits of the 21 st century. In the light of a universal phrase that, "There is always room for improvement"; the ICTs are being improved in terms of their capacities and capabilities with advanced features. It spurs enormous opportunities and opens up a great number of avenues for applying the advanced ICTs in all areas life along with education and training (Chassignol, Khoroshavin, \& Bilyatdinova, 2018; Hussain, 2005). In education and training, there seems a greater demand of advanced ICTs particularly for instruction, assessment and the award of the degrees or credentials to the graduates individually and their recognition across the globe (Hussain \& Cakir, 2020). It seems to be nourishing for flourishing the internationalization featured with learning and working environments of competitive nature. It requires new skills for learning and new ways of working. Apparently, it is creating massive opportunities of human's interaction with technology which is often said "human-technology interactions" (PwC, 2018; Hussain \& Durrani, 2012). Similarly, the advanced ICTs i.e. the digital technologies have seemingly transformed the scenario of education and training through novel pedagogy and assessment methods (Alnahdi, 
2019); and the ways of awarding the degrees and/ or credentials or credentialing (deBittencourt, Goedert, Sharma \& Bortolozzi, 2020). These innovative methods of instruction and the award of credentials consist of capturing, recognition, and validation of the learning outcomes which in broader sense would be of varied nature and associated as a lifelong learning process with graduates (Hussain \& Cakir, 2020; VanLehn, 2011; Woolf, 2009; AAAI, 1994).

Our present is a digital era where instruction and instructional process becomes a skillful task and teachers have to learn (and/ or upgrade their) skills of teaching with technologies (Hussain, 2012). Traditionally, teacher-based instruction has been the norm of educational institutions including the universities (Hussain, 2013). But the innovations seemingly have introduced studentbased instructional process and intelligent teaching system -intelligent tutoring. Now the intelligent system -the artificial intelligence facilitates the teacher even in the classroom (AAAI, 2008) by providing accommodating and individualized learning opportunities (Srinivasan, \& Chawla, 2017) which justifies the learning demands of learners in $21^{\text {st }}$ century.

Keeping in view this backdrop one can observe some innovative and popular instructional platforms or tools including the 'Google Classroom'. Similarly, the sophisticated learning tools like 'Virtual Reality' (VR), 'Augmented Reality' (AR) and 'Artificial Intelligence' (AI) appear with their instructional role in education and training. One can witness through training in delicate and sophisticated areas like surgery, training of pilots and astronauts etc. (Chassignol, Khoroshavin \& Bilyatdinova, 2018, p. 17; QANU, 2015). However, artificial intelligence seems to be more appealing for students and more promising for instruction and instructional process (Ma, Adesope, Nesbit, \& Liu, 2014). By observing its potential role, Tuomi (2018) anticipated the future of instruction to be associated with AI. It suggests the institutions of higher education and universities to be empowered with it to meet the learning demands of students by changing the ways and means of instructional delivery according to the changing learning contexts or environments ( $\mathrm{Ma}, 2019$; US GAO, 2018).

\subsection{The Artificial Intelligence and Its Instructional Role}

In 1986 Henry M. Half the Chief Scientist at Half Resources Inc. informed about the tutoring capability of computer programs (Half, 1986, p.24). In its accordance, now the artificial intelligence which is regarded as a newest advancement in ICTs is being used successfully in education and training (Cowen, 2019) for instructional purpose. It is machine intelligence which 
works like human intelligence to solve problems and make appropriate decisions. It is computer based intelligence which works in close association with human mind (Shabbir \& Anwer, 2015; Hussain, 2005). The human mind is its architect and it works like it for the humans.

The knowledge is stored in computers through specific programs or programming in such a way that it works like human intelligence when applied to solve the problems (Moursund, 2006). AI is widely used by instructors and learners through its applications (apps) like [instructional] robots (Ma, 2019; Nwana, 1990) and/ or tools. Such tools are also being used in education -content development, student assessment, and communication along with their instructional use (Chassignol, Khoroshavin \& Bilyatdinova, 2018) and students' [academic] support services guiding and facilitating them (Zeide, 2019; Zawacki-Richter, Marín, Bond, \& Gouverneur, 2019). Hence, undoubtedly, in future the higher education will depend on AI (Contact North, 2018).

The artificial intelligence (AI) is being used in education at an enhanced momentum. It plays an important role in effective instructional process at university level (Garrido, 2012). It is promoting opportunities of personalized, flexible and customized learning (Srinivasan \& Chawla, 2017), meaningful feedback on students' performance and makes instructional process more interesting (Popenici \& Kerr, 2017; Mason, Khan \& Smith, 2016) to involve students. It makes instructional process easy and efficient by presenting information in a logical-way (Hearst, 1994; Luger, 2009; Russell, \& Norvig, 2010).

Opening up a number of avenues in education (Sisodiya \& Singhal, 2019) it can facilitate the potential researchers and [educational] practitioners to work in a better way (Langley, 2019, p. 9676). It has classroom implications as teachers can use it to know the students' understanding level of the discussed lessons in the class (Borge, 2016). Besides, it is found to be a viable [tool] methodology for professional activities of a teacher which resultantly improves the creative educational environment (Vlasova, Goncharova, Barakhsanova, Karpova, \& Ilina, 2019) for effective teaching and learning. Apparently, different tools and technology-enhanced system have been created to cater the instructional needs of teachers and learning demands of students. Amongst others, the automated writing evaluation (AWE) system [which is an AI tool] was found to be effective tool in helping university students in improving their writing in English [language] in China. It appeared to be time saving, created interest among students, and provided instant and 
clear feedback for improvement (Lu, 2019). AI appeared as an opportunity in education to facilitate teachers by helping them particularly in instructional tasks (Zeide, 2019; Popenici, \& Kerr, 2017). Generally, tutoring (which also called Intelligent Tutoring Systems -ITS), personalized learning, testing and automating tasks are the AI-based functions in education. AI promotes personalized learning or tailoring instruction to fit individually with student's learning needs; and blended instruction i.e. embracing technology in face-to-face interaction (Sisodiya, \& Singhal, 2019; Zawacki-Richter, Marín, Bond, \& Gouverneur, 2019). It would increase learning performance and decrease gaps of achievement among students. The personalized learning is advised to increase independence and motivation of students to learn and their engagement in academic activities for better achievement (Sisodiya, \& Singhal, 2019; Lu, \& Harris, 2018; Woolf, 2015).

The worthwhile developments and innovations in AI regarding its application in education seem to be useful and promising for instructional purpose. But at the same time it is unlikely and unrealistic that AI can replace the 'human teaching' (Ocaña-Fernandez, Valenzuela-Fernandez, \& Garro-Aburto, 2019) which is of much more significance in the age of machines. Although AI can transfer knowledge i.e. can teach in a better way than people or humans but character building i.e. cultivation of pro-social behavior, ethics and morality polished with love and affection are still big challenges to meet by AI (Zeide, 2019; Zhao \& Liu, 2018).

\subsection{Objectives of Study}

This study was conducted to (a) ascertain the attitude of university teachers and students towards the role of artificial intelligence in imparting personalized instruction; (b) discern the perception of university teachers and students on the role of AI in creating adapted groups of students for effective learning; (c) examine the attitude of university teachers and students about the role of $\mathrm{AI}$ in maintaining objectivity and equality in instructional process; and (d) determine the perspective of university teachers and students about the role of AI in saving time and making instructional process efficient and productive.

\section{Methodology}

This study adopted the research methodology already used by the researchers (Hussain, Cakir \& Candeğer, 2018) for study of alike nature. This study was conducted to determine the instructional role of $\mathrm{AI}$ as perceived by the university teachers and students; and hence it was a non-experimental and exploratory-descriptive in nature. It is based on the assertion that such 
studies describe the situations in detail (Polit, Hungler \& Beck, 2001); and the descriptive research portrays the situation(s) in natural way (Burns \& Grove, 2003). Descriptive studies, in social sciences are commonly conducted to describe and/or explain the situation(s) as it/ these exist (Gay, 1999; Frankfort-Nachmias \& Nachmias, 1996). Justifiably, it can be used to make judgment(s) after going systematically through the current situations and/ or practices. Therefore, keeping in view its significance as described by (Hussain, Cakir \& Candeğer, 2018), the descriptive research method was used to ascertain the perception of university teachers and students about the instructional role of artificial intelligence at university level. This small scale study was delimited to the students and teachers of from the departments of social sciences, The Islamia University of Bahawalpur, Pakistan. Therefore, the researcher used survey approach for data collection as it is considered appropriate in social sciences (Blaxter, Hughes, \& Tight, 2002; Polit, Hungler \& Beck, 2001) for exploratory studies.

\subsection{Population and Sampling}

This study consisted of two cohorts of population i.e. university students and their teachers i.e. university teachers. The students of Bachelor Studies Programmes from the Departments of Social Sciences and who were studying in their final semesters were selected as one of the two cohorts of population of the study. The university teachers or faculty who were teaching to these students was taken second cohort of the population of study. The researcher selected subjects of the study through convenient-cum-purposive sampling technique(s) because of the two reasons; firstly, students and their teachers who were using internet and AI tools (search engines, Google translator etc.) daily and who have an android phone (with smart applications or apps) during their university life were included in the sample; and it justifies purposive sampling; and secondly, it was managed by the researcher himself without any sponsorship from any organization or individual and it had its constraints of time and cost. It justifies convenient sampling technique for the study (Hussain, Cakir \& Candeğer, 2018).

Firstly the researcher contacted university teachers and explained to them the purpose of the research, its methods and scope individually in their respective departments. Different aspects of the study, research tools and modalities of data collection were negotiated and finally they agreed to participate in the survey. After getting consent of the teachers; the researcher contacted university students in their respective departments after their class time with the permission and 
help of their respective class teachers. They were also briefed about the survey i.e. its objectives, process of data collection and confidentiality of the data. A total of 380 Bachelor Studies Students and 220 their teachers who were using internet and AI tools (search engines, Google translator etc.) and having an android phone (with smart applications or apps) were agreed to participate in the survey on volunteer basis.

\subsection{Tool for Data Collection}

It was a quantitative study of the descriptive and exploratory nature which was based on sample-survey for data collection. After literature review two questionnaires on five-point rating scale were prepared by the researcher. The questionnaires were prepared according to the objectives and nature of the study; and the main themes identified during literature review by the researcher. These themes are given as headings of the tables in 'findings' section. Both of the tools were validated through their pilot testing on 30 students and 10 teachers' and through the expert's

opinion. The tools were finalized according to results of pilot testing and experts' opinion by modifying and rephrasing some statements. The reliability coefficient was .78 for the questionnaire of university students and .81 for those of their teachers. A thorough proof reading of the tool was done before its implementation for data collection.

\subsection{Procedure of Data Collection and Implementation of Research Tools}

The data was collected with the help of two M. Phil and two $\mathrm{Ph}$. D students who trained as data collectors. A training session on "procedure of data collection" was organized by the principal researcher in the Department of Education for data collectors. Thus trained data collectors implemented the research tools for pilot testing under the supervision of the principal researcher. After this exercise and finalization of the tools; and by getting permission of the respondents and mutually deciding the formalities of data collection the data collectors administered the research tools and collected data from the respondents. The respondents participated in the survey on volunteer basis. The participants were being briefed about the study and procedure of data collection by the data collectors. The confidentiality of the data was also ensured to the participants of the study. The tool was administered on 380 Bachelor Studies Students and 220 their teachers but the response rate was $85 \%$ and $89 \%$ for university students and their teachers as 323 and 196 questionnaires completed in all respects were received back respectively.

\subsection{Considering Research Ethics}


The researcher and data collectors fully observed ethics of research in social sciences.

\subsection{Data Analysis Techniques}

After completing the process of data collection the data collectors entered the data in MS Excel data sheets which already were coded according to the questionnaires. The data of both of the questionnaires was entered separately in the respective coded sheet. As the present study was conducted to evaluate the perception of university teachers and students about instructional role of artificial intelligence; hence descriptive statistics i.e. percentage was used for data analysis. It explains the situation in a simple without any technical difficulty. The scale values from highest 05 strongly agreed (SA) to lowest 01 strongly disagreed (SDA) were used for the purpose. The analyzed data is presented in tabular form along with findings of the study in the next section of the paper.

\section{Data Analysis}

\section{Data Analysis of the Questionnaire of University Students}

The data analysis and findings of the study are given below:-

Table 1. Opinion of university students about the role of artificial intelligence in promoting personalized learning and instruction

\begin{tabular}{|c|c|c|c|c|c|c|c|c|c|c|}
\hline \multirow{3}{*}{ Statement } & \multicolumn{10}{|c|}{ Level of agreement } \\
\hline & \multicolumn{2}{|c|}{ SA } & \multicolumn{2}{|c|}{ A } & \multicolumn{2}{|c|}{ UNC } & \multicolumn{2}{|c|}{ DA } & \multicolumn{2}{|c|}{ SDA } \\
\hline & $f$ & $\%$ & $f$ & $\%$ & $f$ & $\%$ & $f$ & $\%$ & $f$ & $\%$ \\
\hline \multicolumn{11}{|c|}{ Personalized Instruction } \\
\hline $\begin{array}{l}\text { Identify potential } \\
\text { of individual } \\
\text { student }\end{array}$ & 136 & 42.11 & 94 & 29.10 & 12 & 3.72 & 53 & 16.41 & 28 & 8.67 \\
\hline $\begin{array}{l}\text { Individualized } \\
\text { instruction }\end{array}$ & 142 & 43.96 & 97 & 30.03 & 9 & 2.79 & 43 & 13.31 & 32 & 9.91 \\
\hline $\begin{array}{l}\text { Accommodating } \\
\text { diversified } \\
\text { learning styles of } \\
\text { students }\end{array}$ & 151 & 46.75 & 96 & 29.72 & 11 & 3.41 & 38 & 11.76 & 27 & 8.36 \\
\hline $\begin{array}{l}\text { Easy } \\
\text { instructional } \\
\text { delivery }\end{array}$ & 149 & 49.23 & 93 & 28.79 & 7 & 2.17 & 35 & 10.84 & 29 & 8.98 \\
\hline
\end{tabular}


International Journal of Distance Education and E- Learning (IJDEEL) Volume V- Issue II (June, 2020)

\begin{tabular}{lcccccccccc}
\hline $\begin{array}{l}\text { Innovative } \\
\text { instructional } \\
\text { styles }\end{array}$ & 133 & 41.18 & 112 & 34.67 & 13 & 4.02 & 37 & 11.46 & 28 & 8.67 \\
\hline $\begin{array}{l}\text { Maintaining } \\
\text { interest of students }\end{array}$ & 138 & 42.72 & 101 & 31.27 & 8 & 2.48 & 46 & 14.24 & 30 & 9.29 \\
& 141.5 & 44.33 & 100.5 & 31.11 & 10 & 3.10 & 42 & 13 & 29 & 8.98 \\
\hline Overall Average & 143 & & & & & & & & & \\
\hline
\end{tabular}

Table 1 shows opinion of university students about the role of artificial intelligence in promoting personalized learning and as well as personalized instruction. According to the data given in the table $71.21 \%$ and $74 \%$ of the respondents were of the opinion that artificial intelligence helps their teachers in identifying learning potential of the students and in imparting instruction on individual basis respectively. Similarly, $76.45 \%$ and $78.02 \%$ of university students viewed that it (artificial intelligence) facilitates university teachers in accommodating diversified learning styles of their students and in instructional delivery in an easy way respectively. According to $75.85 \%$ of the respondents artificial intelligence plays an important role in adopting innovative instructional styles whereas, $74 \%$ were of the opinion that it maintains interest of students in their studies. In overall majority $(75.44 \%)$ of the university students were of the view that artificial intelligence promotes personalized learning as well as personalized instruction.

Table 2. Opinion of university students on the role of artificial intelligence in creating adapted learning groups of students for effective learning

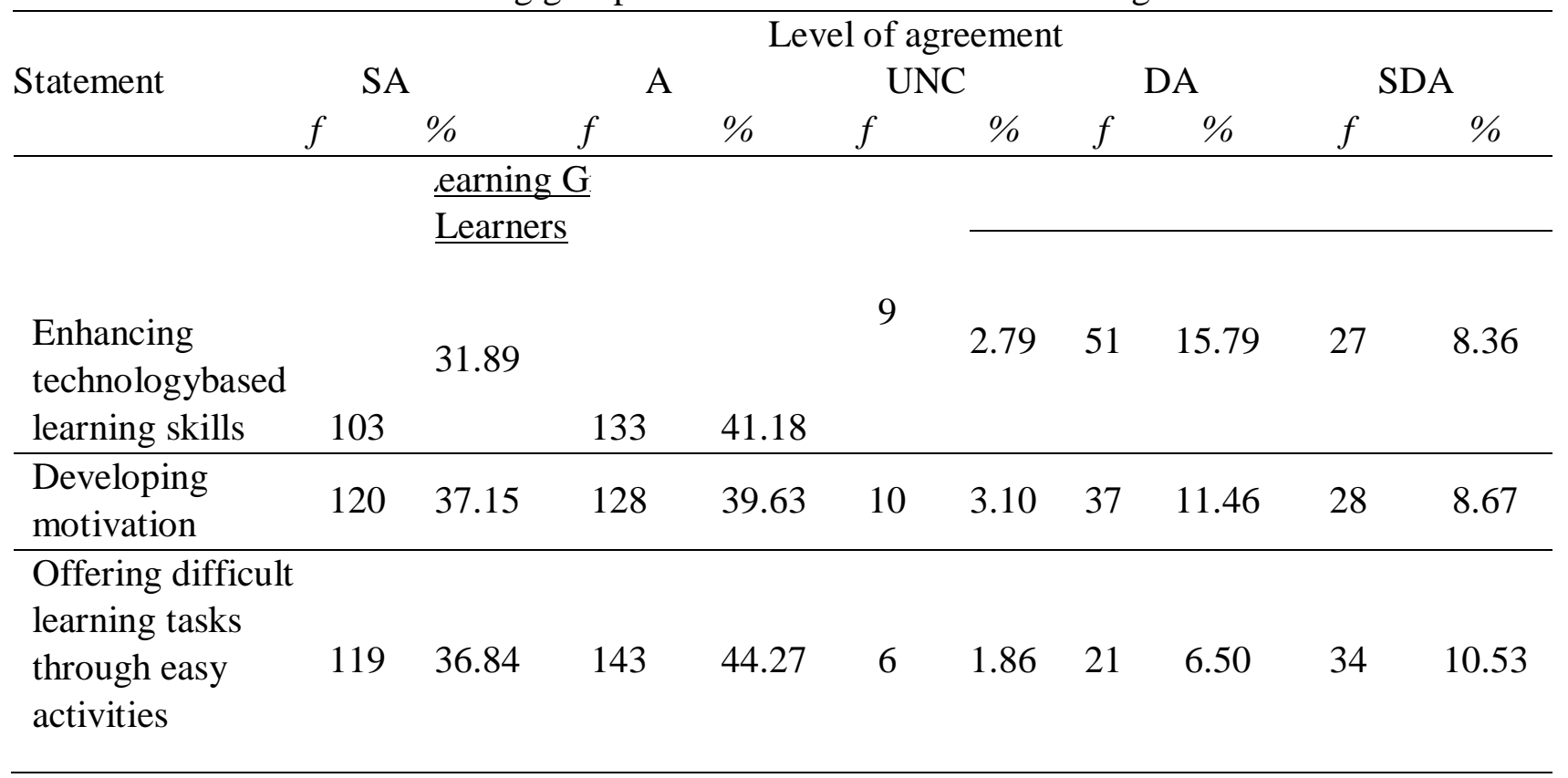


International Journal of Distance Education and E- Learning (IJDEEL) Volume V- Issue II (June, 2020)

\begin{tabular}{lcccccccccc}
\hline $\begin{array}{l}\text { Accommodat ing } \\
\text { learners' pace }\end{array}$ & 162 & 50.15 & 116 & 35.91 & 7 & 2.17 & 16 & 4.95 & 22 & 6.81 \\
\hline $\begin{array}{l}\text { Enhancing } \\
\text { learning capacity } \\
\text { of individual } \\
\text { students }\end{array}$ & 137 & 42.41 & 118 & 36.53 & 8 & 2.48 & 26 & 8.05 & 34 & 10.53 \\
\hline $\begin{array}{l}\text { Fulfils learning } \\
\text { needs of students }\end{array}$ & 109 & 33.75 & 143 & 44.27 & 12 & 3.72 & 23 & 7.12 & 36 & 11.15 \\
& & & & & & & & & & \\
\hline
\end{tabular}

Table 2 indicates views of the university students on the role of artificial intelligence in creating adapted learning groups of students for their effective learning. The data analysis reveals that $73.07 \%$ and $76.78 \%$ of the respondents affirmed useful the role of artificial intelligence in enhancing technology-based learning skills and in developing motivation among students respectively. Whereas, $81.1 \%$ and $86.06 \%$ of the university students were of the opinion that it plays an important role in offering difficult learning tasks through easy activities and in accommodating learners' pace respectively when teachers use it for instructional purpose. Even so, $78.94 \%$ and $78.02 \%$ of the respondents asserted that it aids instructional process by enhancing learning capacity of students individually and fulfilling their learning needs respectively. In overall majority of the university students (79\%) affirmed the role of AI in creating adapted learning groups of students for their effective learning.

Table 3. Opinion of university students about the role of artificial intelligence in maintaining objectivity and equality in instructional process

Level of agreement

\begin{tabular}{|c|c|c|c|c|c|c|c|c|c|c|}
\hline \multirow[t]{2}{*}{ Statement } & \multicolumn{2}{|c|}{ SA } & \multicolumn{2}{|c|}{ A } & \multicolumn{2}{|c|}{ UNC } & \multicolumn{2}{|c|}{ DA } & \multicolumn{2}{|c|}{ SDA } \\
\hline & $f$ & $\%$ & $f$ & $\%$ & $f$ & $\%$ & $f$ & $\%$ & $f$ & $\%$ \\
\hline \multicolumn{11}{|c|}{ Objectivity and equality in instructional process } \\
\hline $\begin{array}{l}\text { Dissemination of } \\
\text { right information } \\
\text { to all students }\end{array}$ & 99 & 30.65 & 155 & 47.99 & 9 & 2.79 & 27 & 8.36 & 33 & 10.22 \\
\hline
\end{tabular}


International Journal of Distance Education and E- Learning (IJDEEL) Volume V- Issue II (June, 2020)

\begin{tabular}{|c|c|c|c|c|c|c|c|c|c|c|}
\hline $\begin{array}{l}\text { Dissemination of up- } \\
\text { to-date information } \\
\text { to all students }\end{array}$ & 112 & 34.67 & 153 & 47.37 & 5 & 1.55 & 22 & 6.81 & 31 & 9.60 \\
\hline $\begin{array}{l}\text { Useful for } \\
\text { inclusive } \\
\text { classroom }\end{array}$ & 137 & 42.41 & 140 & 43.34 & 4 & 1.24 & 17 & 5.26 & 25 & 7.74 \\
\hline $\begin{array}{l}\text { Performing unbiased } \\
\text { role in instructional } \\
\text { process }\end{array}$ & 166 & 51.39 & 113 & 34.98 & 6 & 1.86 & 14 & 4.33 & 24 & 7.43 \\
\hline $\begin{array}{l}\text { Maintaining pace of } \\
\text { instructional process }\end{array}$ & 157 & 48.61 & 109 & 33.75 & 5 & 1.55 & 33 & 10.22 & 19 & 5.88 \\
\hline $\begin{array}{l}\text { Facilitate students } \\
\text { round the clock }\end{array}$ & 149 & 46.13 & 122 & 37.77 & 6 & 1.86 & 29 & 8.98 & 17 & 5.26 \\
\hline Overall Average & 136.67 & 42.31 & 132 & 40.87 & 5.83 & 1.8 & 23.67 & 7.33 & 24.83 & 7.69 \\
\hline
\end{tabular}

The table 3 demonstrates perception of university students about the role of artificial intelligence in maintaining objectivity and equality of and/ or in the instructional process. The table depicts that $78.64 \%$ and $82.04 \%$ of the respondents acknowledged the role of artificial intelligence in disseminating the right and up-to- date/ latest instructional information respectively to all students without any discrimination. Similarly, $85.75 \%$ and $86.37 \%$ of the respondents affirmed that artificial intelligence plays useful role for challenged students in inclusive classrooms and makes instructional process unbiased and/ or equitable respectively. Likewise, $82.36 \%$ and $83.90 \%$ of the respondents acknowledged the role of artificial intelligence in instructional process in maintaining pace of the instruction and in facilitating students objectively round the clock respectively. In overall majority (73.18\%) of the university students affirmed the role of artificial intelligence in maintaining objectivity and equality of and/ or in the instructional process.

Table 4. Opinion of the respondents about the role of artificial intelligence in saving time and making instructional process efficient and productive

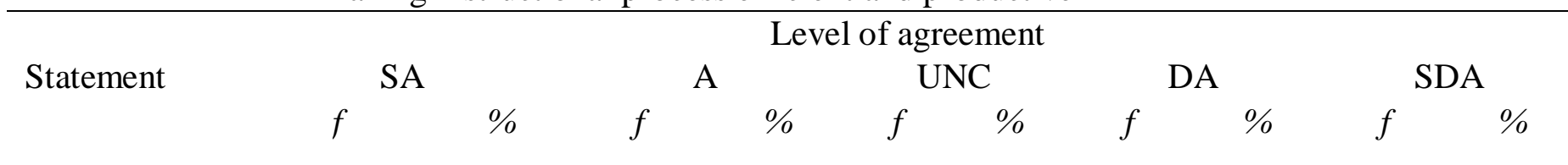

Time saving 
International Journal of Distance Education and E- Learning (IJDEEL) Volume V- Issue II (June, 2020)

\begin{tabular}{|c|c|c|c|c|c|c|c|c|c|c|}
\hline $\begin{array}{l}\text { Efficient } \\
\text { instructional } \\
\text { process }\end{array}$ & 140 & 43.34 & 127 & 39.32 & 7 & 2.17 & 27 & 8.36 & 22 & 6.81 \\
\hline $\begin{array}{l}\text { Intelligent } \\
\text { tutoring system }\end{array}$ & 146 & 45.20 & 126 & 39.01 & 5 & 1.55 & 25 & 7.74 & 21 & 6.50 \\
\hline $\begin{array}{l}\text { Provide } \\
\text { customized } \\
\text { support and } \\
\text { instruction }\end{array}$ & 98 & 30.34 & 143 & 44.27 & 12 & 3.72 & 32 & 9.91 & 38 & 11.76 \\
\hline Anytime tutoring & 128 & 39.63 & 132 & 40.17 & 3 & 0.93 & $2 \underline{3}$ & 7.12 & 37 & 11.46 \\
\hline $\begin{array}{l}\text { Bridges gap of } \\
\text { technology skills of } \\
\text { students }\end{array}$ & 99 & 30.65 & 137 & 42.41 & 4 & 1.24 & 48 & 14.86 & 35 & 10.84 \\
\hline $\begin{array}{l}\text { Timely feedback } \\
\text { on students' work }\end{array}$ & 119 & 36.84 & 143 & 44.27 & 6 & 1.86 & 21 & 6.50 & 34 & 10.53 \\
\hline $\begin{array}{l}\text { Useful feedback } \\
\text { on students' work }\end{array}$ & 151 & 46.75 & 96 & 29.72 & 11 & 3.41 & 38 & 11.76 & 27 & 8.36 \\
\hline Overall Average & 125.86 & 38.96 & 129.14 & 39.88 & 6.86 & 2.13 & 30.57 & 9.47 & 30.57 & 9.47 \\
\hline
\end{tabular}

The table 4 describes the attitude of the respondents towards the role of artificial intelligence in saving time and making instructional process efficient and productive. The data analysis affirmed that $82.66 \%$ and $84.21 \%$ of the respondents were of the view that the use of artificial intelligence makes instructional process more efficient and responds well through its intelligent tutoring system (ITS) respectively. Similarly, $74.61 \%$ and $79.80 \%$ of the respondents were of the opinion that AI provides customized support $\&$ instruction to the students and extends facility of tutoring round the clock respectively. Even so, $73.06 \%$ of the university students acknowledged its role in bridging the gap of technology skills of the students as they can learn through ITS. Likewise, $81.11 \%$ and $76.47 \%$ of the respondents were of the opinion that by using artificial intelligence in instructional process their teachers provide timely according to the schedule and useful \& objectivity-based feedback respectively on their work. In overall majority (78.84\%) of the university students demonstrated their positive attitude towards the role of artificial intelligence in saving time and making instructional process more efficient and more productive. 
International Journal of Distance Education and E- Learning (IJDEEL) Volume V- Issue II (June, 2020)

\section{Data Analysis of Questionnaire for Teachers}

Findings from the data analysis of the questionnaire for university teachers are given below:-

Table 5. Opinion of university teachers on the role of artificial intelligence in promoting personalized instruction

\begin{tabular}{|c|c|c|c|c|c|c|c|c|c|c|}
\hline \multirow{3}{*}{ Statement } & \multicolumn{10}{|c|}{ Level of agreement } \\
\hline & \multicolumn{2}{|c|}{ SA } & \multicolumn{2}{|r|}{ A } & \multicolumn{2}{|r|}{ UNC } & \multicolumn{2}{|r|}{ DA } & \multicolumn{2}{|c|}{ SDA } \\
\hline & $f$ & $\%$ & $f$ & $\%$ & $f$ & $\%$ & & $f \quad \%$ & $f$ & $\%$ \\
\hline \multicolumn{11}{|c|}{ Personalized Instruction } \\
\hline $\begin{array}{l}\text { Identify } \\
\text { potential of } \\
\text { individual } \\
\text { student }\end{array}$ & 82 & 41.84 & 98 & 50.0 & 2 & 1.02 & 11 & 5.61 & 3 & 1.53 \\
\hline $\begin{array}{l}\text { Individualized } \\
\text { instruction }\end{array}$ & 78 & 39.80 & 102 & 52.04 & 3 & 1.53 & 7 & 3.57 & 6 & 3.06 \\
\hline $\begin{array}{l}\text { Accommodati } \\
\text { ng diversified } \\
\text { learning styles } \\
\text { of students }\end{array}$ & 87 & 44.39 & 99 & 50.51 & 2 & 1.02 & 5 & 2.55 & 3 & 1.53 \\
\hline $\begin{array}{l}\text { Easy } \\
\text { instructional } \\
\text { delivery }\end{array}$ & 76 & 38.78 & 82 & 41.84 & 8 & 4.08 & 18 & 9.18 & 12 & 6.12 \\
\hline $\begin{array}{l}\text { Innovative } \\
\text { instructional } \\
\text { styles }\end{array}$ & 79 & 40.31 & 83 & 42.35 & 6 & 3.06 & 11 & 5.61 & 17 & 8.67 \\
\hline $\begin{array}{l}\text { Maintaining } \\
\text { interest of } \\
\text { students }\end{array}$ & 88 & 44.90 & 101 & 51.53 & 00 & 00 & 4 & 2.04 & 3 & 1.53 \\
\hline $\begin{array}{l}\text { Overall } \\
\text { Average }\end{array}$ & 81.67 & 41.67 & 94.17 & 48.04 & 3.50 & 1.79 & 9.33 & 4.76 & 7.33 & 3.74 \\
\hline
\end{tabular}

The data analysis given in the table 5 reflects opinion of the university teachers on the role of artificial intelligence in facilitating them for personalized instructional delivery. According to the data given in the table 5; in overall $91.84 \%$ and $91.84 \%$ of the respondents were of the opinion 
that artificial intelligence helps them in identifying learning potential of their students and imparting instruction on individual basis respectively. Similarly, $94.90 \%$ and $80.62 \%$ of university teachers viewed that it (artificial intelligence) facilitates them in accommodating diversified learning styles of their students and instructional delivery in a stress-free way i.e. it helps them in instructional delivery with peace of mind. According to $82.66 \%$ of the respondents artificial intelligence plays an important role in adopting innovative instructional styles (blended learning) whereas, $96.43 \%$ were of the opinion that it maintains interest of their students in their studies. In overall majority $(89.71 \%)$ of the university teachers acknowledged the role of artificial intelligence in facilitating them for personalized instructional delivery.

Table 6. Opinion of the university teachers on the role of artificial intelligence in creating adapted groups of their students for their effective instruction

\begin{tabular}{|c|c|c|c|c|c|c|c|c|c|c|}
\hline \multirow{3}{*}{ Statement } & \multicolumn{10}{|c|}{ Level of agreement } \\
\hline & \multicolumn{2}{|c|}{ SA } & \multicolumn{2}{|c|}{ A } & \multicolumn{2}{|c|}{ UNC } & \multicolumn{2}{|c|}{ DA } & \multicolumn{2}{|c|}{ SDA } \\
\hline & $f$ & $\%$ & $f$ & $\%$ & $f$ & $\%$ & $f$ & $\%$ & $f$ & $\%$ \\
\hline \multicolumn{11}{|c|}{ Creating Adapted Groups of Students/ Learners } \\
\hline $\begin{array}{l}\text { Enhancing } \\
\text { learning } \\
\text { skills }\end{array}$ & 66 & 33.67 & 112 & 57.14 & 4 & 2.04 & 6 & 3.06 & 8 & 4.08 \\
\hline $\begin{array}{l}\text { Developing } \\
\text { motivation }\end{array}$ & 59 & 30.10 & 113 & 57.65 & 3 & 1.53 & 9 & 4.59 & 12 & 6.12 \\
\hline $\begin{array}{l}\text { Offering } \\
\text { difficult } \\
\text { learning tasks } \\
\text { in easy way }\end{array}$ & 60 & 30.61 & 109 & 55.61 & 5 & 2.55 & 8 & 4.08 & 14 & 7.14 \\
\hline $\begin{array}{l}\text { Accommodat } \\
\text { ing learners' } \\
\text { pace }\end{array}$ & 66 & 33.67 & 112 & 57.14 & 00 & 00 & 6 & 3.06 & 12 & 6.12 \\
\hline $\begin{array}{l}\text { Enhancing } \\
\text { learning } \\
\text { ability of } \\
\text { individual } \\
\text { students }\end{array}$ & 76 & 38.78 & 111 & 56.63 & 1 & 0.51 & 2 & 1.02 & 6 & 3.06 \\
\hline $\begin{array}{l}\text { Fulfils } \\
\text { learning } \\
\text { needs of } \\
\text { students }\end{array}$ & 76 & 38.78 & 114 & 58.16 & 00 & 00 & 3 & 1.53 & 3 & 1.53 \\
\hline $\begin{array}{l}\text { Overall } \\
\text { Average }\end{array}$ & 67.17 & 34.27 & 111.83 & 57.06 & 2.16 & 1.10 & 5.67 & 2.89 & 9.17 & 4.68 \\
\hline
\end{tabular}




$$
N^{\square}=196
$$

The table 6 indicates perception of the university teachers on the role of artificial intelligence in creating adapted learning groups of their students -for effectiveness of their instructional delivery and learning of students. The data analysis reveals that $90.81 \%$ and $87.75 \%$ of the respondents affirmed the role of artificial intelligence in enhancing technology-based learning skills and in developing motivation among their students respectively. Whereas, $86.22 \%$ and $90.81 \%$ of the respondents asserted that it plays an important in offering difficult learning tasks through easy activities and in accommodating learners' pace respectively when they [teachers] use it for instructional purpose. Even so, $95.41 \%$ and $97.94 \%$ of the respondents acknowledged that it aids instructional process by enhancing learning ability of their students individually and in fulfilling their learning needs respectively. In overall a prominent majority (91.33\%) of the university teachers were of opinion that AI plays a useful role in creating adapted learning groups of their students -for effectiveness of their [teachers'] instructional delivery and learning of students.

Table 7. Opinion of university teachers about the role of artificial intelligence in maintaining objectivity and equality in instructional process

\begin{tabular}{|c|c|c|c|c|c|c|c|c|c|c|}
\hline \multirow{3}{*}{ Statement } & \multicolumn{10}{|c|}{ Level of agreement } \\
\hline & \multicolumn{2}{|c|}{ SA } & \multicolumn{2}{|c|}{ A } & \multicolumn{2}{|c|}{ UNC } & \multicolumn{2}{|c|}{ DA } & \multicolumn{2}{|c|}{ SDA } \\
\hline & $f$ & $\%$ & $f$ & $\%$ & $f$ & $\%$ & $f$ & $\%$ & $f$ & $\%$ \\
\hline \multicolumn{11}{|c|}{ Objectivity and equality in instructional process } \\
\hline $\begin{array}{l}\text { Dissemination } \\
\text { of right } \\
\text { information to } \\
\text { all students }\end{array}$ & 77 & 39.29 & 117 & 59.69 & 00 & 00 & 2 & 1.02 & 00 & 00 \\
\hline $\begin{array}{l}\text { Dissemination } \\
\text { of up-to-date } \\
\text { information to } \\
\text { all students }\end{array}$ & 78 & 39.80 & 118 & 60.20 & 00 & 00 & 00 & 00 & 00 & 00 \\
\hline $\begin{array}{l}\text { Useful for } \\
\text { inclusive } \\
\text { classroom }\end{array}$ & 86 & 43.88 & 110 & 56.12 & 00 & 00 & 00 & 00 & 00 & 00 \\
\hline $\begin{array}{l}\text { Performing } \\
\text { unbiased role } \\
\text { in } \\
\text { instructional } \\
\text { process }\end{array}$ & 96 & 48.98 & 99 & 50.51 & 00 & 00 & 1 & 0.51 & 00 & 00 \\
\hline
\end{tabular}


International Journal of Distance Education and E- Learning (IJDEEL) Volume V- Issue II (June, 2020)

\begin{tabular}{lcccccccccc}
\hline $\begin{array}{l}\text { Maintaining } \\
\text { pace of } \\
\text { instructional } \\
\text { process }\end{array}$ & 93 & 47.45 & 101 & 51.53 & 1 & 0.51 & 1 & 0,51 & 00 & 00 \\
\hline $\begin{array}{l}\text { Facilitate } \\
\text { students round } \\
\text { the clock }\end{array}$ & 90 & 45.90 & 103 & 52.55 & 2 & 1.02 & 1 & 0.51 & 00 & 00 \\
\hline $\begin{array}{l}\text { Overall } \\
\text { Average }\end{array}$ & 86.67 & 44.22 & 108 & 55.1 & 0.5 & 0.26 & 0.83 & 0.42 & 00 & 00 \\
\hline & & & & & & & & & & $N^{\square}=196$
\end{tabular}

The table 7 demonstrates the viewpoint of the university teachers about the role of artificial intelligence in maintaining objectivity and equality in instructional process. The table portrays that $98.98 \%$ and all i. e. $100 \%$ of the respondents acknowledged the role of artificial intelligence in disseminating the right and up-to- date/ latest instructional information respectively to all of their students without any discrimination. Similarly, all (100\%) and 99.49\% of the respondents affirmed that artificial intelligence plays a useful role for the challenged students in inclusive classrooms and it makes the instructional process unbiased and/ or equitable respectively. Likewise, $98.98 \%$ and $98.45 \%$ of the respondents acknowledged the role of artificial intelligence in instructional process to be useful in maintaining pace of the instruction and in facilitating their students round the clock. In overall almost all (99.23\%) of the university teachers acknowledged the role AI in maintaining objectivity and equality in instructional process.

Table 8. Opinion of the respondents about the role of artificial intelligence in saving time and making instructional process efficient and productive

\begin{tabular}{|c|c|c|c|c|c|c|c|c|c|c|}
\hline \multirow{3}{*}{ Statement } & \multicolumn{10}{|c|}{ Level of agreement } \\
\hline & \multicolumn{2}{|c|}{ SA } & \multicolumn{2}{|c|}{ A } & \multicolumn{2}{|c|}{ UNC } & \multicolumn{2}{|c|}{ DA } & \multicolumn{2}{|c|}{ SDA } \\
\hline & $f$ & $\%$ & $f$ & $\%$ & $f$ & $\%$ & $f$ & $\%$ & $f$ & $\%$ \\
\hline Time saving & & & & & & & & & & \\
\hline $\begin{array}{l}\text { Efficient } \\
\text { instructional } \\
\text { process }\end{array}$ & 89 & 45.41 & 106 & 54.08 & 1 & 0.51 & 00 & 00 & 00 & 00 \\
\hline $\begin{array}{l}\text { Intelligent } \\
\text { tutoring system }\end{array}$ & 81 & 41.33 & 98 & 50.0 & 00 & 00 & 11 & 5.61 & 6 & 3.06 \\
\hline $\begin{array}{l}\text { Provide } \\
\text { customized } \\
\text { support and } \\
\text { instruction }\end{array}$ & 86 & 43.88 & 98 & 50.0 & 2 & 1.02 & 4 & 2.04 & 6 & 3.06 \\
\hline
\end{tabular}


International Journal of Distance Education and E- Learning (IJDEEL) Volume V- Issue II (June, 2020)

\begin{tabular}{|c|c|c|c|c|c|c|c|c|c|c|}
\hline Anytime tutoring & 83 & 42.35 & 105 & 53.57 & 1 & 0.51 & 3 & 1.53 & 4 & 2.04 \\
\hline $\begin{array}{l}\text { Bridges gap of } \\
\text { technology } \\
\text { skills of students }\end{array}$ & 97 & 49.49 & 98 & 50.0 & 1 & 0.51 & 00 & 00 & 00 & 00 \\
\hline $\begin{array}{l}\text { Timely } \\
\text { feedback on } \\
\text { students' work }\end{array}$ & 105 & 53.57 & 91 & 46.43 & 00 & 00 & 00 & 00 & 00 & 00 \\
\hline $\begin{array}{l}\text { Useful } \\
\text { feedback on } \\
\text { students' work }\end{array}$ & 102 & 52.04 & 94 & 47.96 & 00 & 00 & 00 & 00 & 00 & 00 \\
\hline $\begin{array}{l}\text { Overall } \\
\text { Average }\end{array}$ & 91.86 & 46.87 & 98.57 & 50.29 & 1.71 & 0.36 & 2.57 & 1.31 & 2.29 & 1.17 \\
\hline
\end{tabular}

The table 8 illustrates perception of the respondents about the role of artificial intelligence in saving time and making instructional process more efficient and more productive. The data analysis acknowledged that $99.49 \%$ and $91.33 \%$ of the respondents were of the view that the use of artificial intelligence makes instructional process more efficient and responds well through its intelligent tutoring system (ITS respectively to facilitate the students. Similarly, $93.88 \%$ and $95.92 \%$ of the respondents were of the view that it provides customized support $\&$ instruction to their students and extends the facility of intelligent tutoring round the clock (according to demand or need of the students) respectively. Even so, $99.49 \%$ of the university teachers acknowledged its role in bridging the gap of technology skills of their students as they can learn through ITS. However, all i. e. $100 \%$ of the respondents were of the opinion that by using artificial intelligence in instructional process they [i. e. teachers] provide timely according to the schedule and useful \& objectivitybased feedback respectively on the work of their students. In overall the prominent majority (97.16\%) of the university teachers affirmed the role of AI in saving time and making instructional process more efficient and more productive.

\section{Discussion and Conclusion}

This study demonstrated positive attitude of university students and teachers towards AI and its instructional role which is encouraging not only for the respondents but the administrators and policy makers also. The study affirmed that in overall majority ( $75.44 \%$ and $89.71 \%$ ) of the university students and teachers were of the view that artificial intelligence promotes personalized 
learning as well as personalized instruction. This corresponds with the assertion of the AAAI (2008) and results of the study of Srinivasan, and Chawla (2017) that the intelligent system -the artificial intelligence facilitates the teacher even in the classroom (AAAI, 2008) by providing "more flexible and personalized models of learning" which is demand of the students in $21 \mathrm{st}$ century (Srinivasan, \& Chawla, 2017, p.4). Similarly, this study affirmed that majority (79\%) of the university students and a prominent majority (91.33\%) of the university teachers were of opinion that AI plays a useful role in creating adapted learning groups of their students -for effectiveness of their [teachers'] instructional delivery and learning of students. Alike finding were reported by corresponding studies which asserted that AI promotes personalized learning or tailoring instruction to fit individually with student's learning needs; and blended instruction i.e. embracing technology in face-to-face interaction (Sisodiya, \& Singhal, 2019; Zawacki-Richter, Marín, Bond, \& Gouverneur, 2019). It would increase learning performance and decrease gaps of achievement among students. The personalized learning is advised to increase independence and motivation of students to learn and their engagement in academic activities for better achievement (Sisodiya, \& Singhal, 2019; Lu, \& Harris, 2018; Woolf, 2015).

Even so, it was acknowledged by the overall majority (73.18\%) of the university students and almost all (99.23\%) of the university teachers acknowledged the role AI in maintaining objectivity and equality of and/ or in the instructional process. Likewise, this study asserted that the overall majority (78.84\%) of the university students and a prominent majority $(97.16 \%)$ of the university teachers demonstrated their positive attitude towards the role of artificial intelligence in saving time and making instructional and learning process more efficient and more productive. The results of the study are supported by the results of some previous studies which described that artificial intelligence (AI) is being used in education at an enhanced momentum. It plays an important role in effective instructional process at university level (Garrido, 2012). It is promoting opportunities of personalized, flexible and customized learning (Srinivasan \& Chawla, 2017) meaningful feedback on students' performance and makes instructional process more interesting (Popenici \& Kerr, 2017; Mason, Khan \& Smith, 2016). It makes instructional process easy and efficient by presenting information in a logical-way (Hearst, 1994; Luger, 2009; Russell, \& Norvig, 2010). This situation urges particularly the institutions of higher education and universities to be empowered with innovations i.e. new digital technologies -the artificial intelligence to meet the 
International Journal of Distance Education and E- Learning (IJDEEL) Volume V- Issue II (June, 2020)

learning demands of students by changing the ways and means of instructional delivery according to the changing learning contexts or environments (Ma, 2019; US GAO, 2018).

Reasonably, here one may raise a questions that, "Would artificial intelligence replace human teaching"? The answer wouldn't be affirmative as in current scenario it seems unlikely and unrealistic to happen that AI can replace the 'human teaching' (Ocaña-Fernandez, ValenzuelaFernandez, \& Garro-Aburto, 2019) which is of much more significance in the age of machines' learning. Although AI can transfer knowledge i.e. can teach in a better way than people or humans do but character building i.e. cultivation of pro-social behavior, ethics and morality polished with love and affection are still big challenges to address (Zeide, 2019; Zhao \& Liu, 2018). It may work as a direction for the future researcher(s) to address these issues.

\section{References}

AAAI (2008). AI Education Colloquium. In Proceedings of the 2008 AAAI Conference, Menlo Park, CA.: AAAI Press.

AAAI (1994). Improving Instruction of Introductory Artificial Intelligence. In Proceedings of the 1994 AAAI Fall Symposium, Menlo Park, CA.: AAAI Press.

Alnahdi, A. (2019). The impact of the use of artificial intelligence in the education sector. International Journal of Artificial Intelligence and Machine Learning, 1(4), 1-8.

Amazon (n.d.). Machine Learning and Deep Learning. Retrieved on 30 March 2020 from https://aws.amazon.com/machine-learning/what-is-ai/

Blaxter, L., Hughes, C., \& Tight, M. (2002). How to Research. $2^{\text {nd }}$ ed. New Delhi, Viva BooksPrivate Limited.

Borge, N. (2016). White Paper -Artificial Intelligence to Improve Education / Learning Challenges. International Journal of Advanced Engineering \& Innovative Technology (IJAEIT), 2(6); 10-13.

Burns, S. N., \& Grove, S. K. (2003). Understanding nursing research. 3rd ed. Philadelphia: Saunders Company.

Chassignol, M., Khoroshavin, A., and Bilyatdinova, A. (2018). Artificial Intelligence trends in education: A narrative overview. Procedia Computer Science 136 (2018) 16-24.

Contact North. (2018). Ten facts about artificial intelligence in teaching and learning. Retrieved on $01 \quad$ March 2020 from

https://teachonline.ca/sites/default/files/toolstrends/downloads/ten_facts_about_artificial_inte lligence.pdf

Cowen, M. (2019). Making the AI journey from theory to practice. Retrieved on 30 March 2020 from https://amadeus.com/en/insights/blog/making-ai-journey-theory-to-practice.

deBittencourt, D. F., Goedert, A. R., Sharma, R. C, \& Bortolozzi, F. (2020). Framework Blockchain Education: Rupture in Higher Education. In Sharma, R. C., Yildirim, H. \& Kurubacak, K. (Eds.), Blockchain Technology Applications in Education (pp. 80-96). Hershey, PA: IGI Global. doi:10.4018/978-1-5225-9478-9.ch004. 
Frankfort-Nachmias, C., \& Nachmias, D. (1996). Research Methods in the Social Sciences. $5^{\text {th }}$ ed. London: Arnold

Gay, L. R. (1999). Educational Research. $5^{\text {th }}$ ed. PTR, Prentice Hall Inc.

Garrido, A. (2012). AI and Mathematical Education. Educational Sciences, 2, 22-32.

Half, H. M. (1986). Instructional Applications of Artificial Intelligence. Educational Leadership, March 1986, 24-31.

Hearst, M. (1994). Preface: Improving Instruction of Introductory AI. In Proceedings of the 1994 AAAI Fall Symposium, Menlo Park, CA.: AAAI Press.

Hussain, I. (2013). A study of learners' reflection on andragogical skills of distance education tutors. International Journal of Instruction; 6(1), 123-138.

Hussain, I. (2012). Study on instructional paradigms of virtual education in Pakistan: A learners' perspective. The Turkish Online Journal of Educational Technology (TOJET); 11(2), 78186.

Hussain, I. (2005). A study of emerging technologies and their impact on teaching learning process. Anunpublished PhD Dissertation, Islamabad, AIOU 2005.

Hussain, I., \& Cakir, O. (2020). Blockchain Technology in Higher Education: Prospects, Issues, and Challenges. In Sharma, R. C., Yildirim, H. \& Kurubacak, K. (Eds.), Blockchain Technology Applications in Education (pp. 97-112). Hershey, PA: IGI Global. doi:10.4018/978-1-5225-9478-9.ch005.

Hussain, I., Cakir, O., \& Candeğer, Ü. (2018). Social Media as a Learning Technology for University Students. International Journal of Instruction, 11(2), 281-296.

Hussain, I. \& Durrani, M. I. (2012). A Study on the Role of Web Technology in Enhancing Research Pursuance among University Teachers. Journal of Educational Technology, 9(3), $32-40$.

Langley, P. (219). An Integrative Framework for Artificial Intelligence Education. In Proceedings of the Ninth AAAI Symposium on Educational Advances in Artificial Intelligence (EAAI19). Association for the Advancement of Artificial Intelligence.

$\mathrm{Lu}, \mathrm{X}$. (2019). An empirical study on the artificial intelligence writing evaluation system in China CET. Big Data 7(2), 121-129, DOI: 10.1089/big.2018.0151.

Lu, J., \& Harris, L. A. (2018). Artificial Intelligence (AI) and Education. Congressional Research Service, In Focus, August, 01, 2018.

Luger, G. (2009). Artificial Intelligence, 6th Ed., Boston, MA.: Addison-Wesley.

Ma, J. (2019). The Challenge and Development of Vocational Education Under the Background of Artificial Intelligence. Advances in Social Science, Education and Humanities Research, 319.

Ma, W., Adesope, O. O., Nesbit, J. C., \& Liu, Q. (2014). Intelligent Tutoring Systems and Learning Outcomes: A Meta-Analysis. Journal of Educational Psychology, 106(4), 901-918.

Mason, J, Khan, K, Smith, S. (2016). Literate, numerate, discriminate-realigning 21 st century skills. In W Chen et al. (Eds.), Proceedings of the $24^{\text {th }}$ international conference on computers in education, (pp. 609-614). Mumbai: Asia-Pacific Society for Computers in Education.

Moursund, D. (2006). Brief Introduction to Educational Implications of Artificial Intelligence.

Oregon, University of Oregon. [http://darkwing.uoregon.edu/ moursund/dave/Free.html.]

Nwana H. (1990). Intelligent tutoring systems: An overview. Artificial Intelligence Review, 1990. 
Ocaña-Fernandez, Y., Valenzuela-Fernandez, L., \& Garro-Aburto, L. (2019). Artificial Intelligence and its Implications in Higher Education. Propósitosy Representaciones, 7(2), 536-568. doi: http://dx.doi.org/10.20511/pyr2019.v7n2.274

Polit, D., Hungler, B., \& Beck, C. T. (2001). Essentials of nursing research: Methods, Appraisal and Utilization. $5^{\text {th }}$ ed. Philadelphia: Lippincott Williams \& Wilkins.

Popenici, S. A. D., \& Kerr, S. (2017). Exploring the impact of artificial intelligence on teaching and learning in higher education. Research and Practice in Technology Enhanced Learning (2017) $12: 22$.

$\mathrm{PwC}$ (2018). Artificial intelligence in India - hype or reality. Retrieved on 30 March 2020 from https://www.pwc.in/consulting/technology/data-and-analytics/artificial-intelligence-inindia-hype-orreality.html.

QANU (2015). Artificial Intelligence academic programmes in the Netherlands: A state of the art report. The Netherlands, Quality Assurance Netherlands Universities.

Russell, S., and Norvig, P. (2010). Artificial Intelligence, 3rd Ed., Upper Saddle River, NJ.: Prentice Hall.

Sisodiya, C. D. S., \& Singhal, S. (2019). The Future Education with Artificial Intelligence. International Journal for Research in Engineering Application \& Management (IJREAM), 5(2), 893-897. DOI : 10.35291/2454-9150.2019.0149.

Shabbir, J., \& Anwer, T. (2015). Artificial Intelligence and its Role in Near Future. Journal of Latex Class Files, 14(8), 1-11. 5

Srinivasan, V., \& Chawla, M. (2017). Digital Systems \& Technology: Helping the Education Industry Learn and Ascend the Digital Technology Curve. Cognizant (NASDAQ-100: CTSH). USA.

Tuomi, I. (2018). The Impact of Artificial Intelligence on Learning, Teaching, and Education. Policies for the future, Eds. Cabrera, M., Vuorikari, R \& Punie, Y., EUR 29442 EN, Publications Office of the European Union, Luxembourg, 2018, ISBN 978-92-79-972577, doi:10.2760/12297, JRC113226.

US GAO. (2018). Artificial Intelligence: Emerging Opportunities, Challenges, and Implications. GAO-18-142SP. United States Government Accountability Office.

VanLehn, K. (2011). The relative effectiveness of human tutoring, intelligent tutoring systems, and other tutoring systems. Educ. Psychol., 46, 197-221.

Vlasova, E. Z., Goncharova, S. V., Barakhsanova, E. A., Karpova, N. A. \& Ilina, T. S. (2019). Artificial intelligence for effective professional training of teachers in the Russian Federation. Revista Espacios, 40(22), 9-20.

Woolf, B. P. (2015). AI and Education: Celebrating 30 years of Marriage, AIED 2015 Workshop Proceedings - Vol. 4, retrieved from http://ceur-ws.org/Vol-1432/ai_ed_pap5.pdf

Woolf, B. P. (2009). Building Intelligent Interactive Tutors: Student-Centered Strategies for Revolutionizing e-Learning. San Francisco, CA: Morgan Kaufmann.

Zawacki-Richter, O., Marín, V. I., Bond, M., \& Gouverneur, F. (2019). Systematic review of research on artificial intelligence applications in higher education - where are the educators? International Journal of Educational Technology in Higher Education, 16:39, $1-27$.

Zeide, E. (2019). Artificial Intelligence in Higher Education: Applications, Promise and Perils, and Ethical Questions. Educause Review, 2019, 31-39. 
International Journal of Distance Education and E- Learning (IJDEEL) Volume V- Issue II (June, 2020)

Zhao, Y., \& Liu, G. (2018). How Do Teachers Face Educational Changes in Artificial Intelligence Era. Advances in Social Science, Education and Humanities Research (ASSEHR), 300, 4750 . 